\title{
Competitiveness of Indonesian banking industry based on commercial bank business group: Panzar Rosse Model
}

\author{
Fajra Octrina $^{1}$; Rike Setiawati ${ }^{2 *}$ \\ 1) Business Administration, Polytechnic LP3I Bandung, Indonesia \\ ${ }^{2)}$ Faculty of Economics and Business, Universitas Jambi, Indonesia \\ *To whom correspondence should be addressed.Email:rike_setiawati@unja.ac.id

\begin{abstract}
The present research was aimed to investigating the competitiveness in Indonesian banking sector during the period of 2005 to 2016, to set the limit of the scope of the study a total sample is 84 banks. This research was conducted by grouping banks based on ownership and based on BUKU (General Bank based on Business Activities). The study also aimed to analyze the banking competitiveness based on classification of banks and groups of capital ownership. The study was conducted by evaluating the value of $\mathrm{H}$ statistic for the research model comprising of three input variables, namely funds, labors and capital. The results of the research show that the market of banking industry in Indonesia is classified as monopolistic competition. The limitation of this study is that this study only looks at the competition variable, and has not seen its relationship with other variables. In subsequent studies, it is expected to conduct research related to competition and relate it to other variables, such as market share or level of market concentration.
\end{abstract}

Keywords: Banking industry, Competition, Panzar Rosse

JEL Classifications: G21, M21

\section{INTRODUCTION}

As a country which has the largest number of banks, based on ownership, Indonesia classifies its banking structure into several groups, consisting of government banks, national private foreign exchange banks, national private non-foreign exchange banks, regional banks (BPD), joint venture banks, and representative offices of foreign banks (Figure 1).

Banks in Indonesia are currently encountering intense competition, given the fact that there is quite large number of banks in Indonesia. In addition, there is also an increase in growth of the bank's business due to the government policies related to banking minimum capital requirement which then led to bank classification into 4 groups of BUKU (General Bank based on Business Activities). The development of banks based on the group of BUKU within the last 3 years $(2014$-2016) can be observed in the Figure 2.

As seen in the Figure 2, the increase in the number of banks since the regulation was enacted in 2014 has undergone a series of changes. Yet, until 2016, the banks within group of BUKU 4 were dominated by the four largest banks in Indonesia (Bank Mandiri, Bank Negara Republik Indonesia, Bank Rakyat Indonesia and Bank Central Asia). On the other hand, the number of banks continued to decrease with a series of mergers and acquisitions in order to realize the minimum capital requirement. As such, it caused high 
concentrated market of the banking industry which led to poor competition of the business. Concentration is ownership of a large number of resources by a certain group of industry players. In fact, an industry will have good and sound business competition provided that the market is not concentrated, or in other words, the industry is not only dominated by large companies.

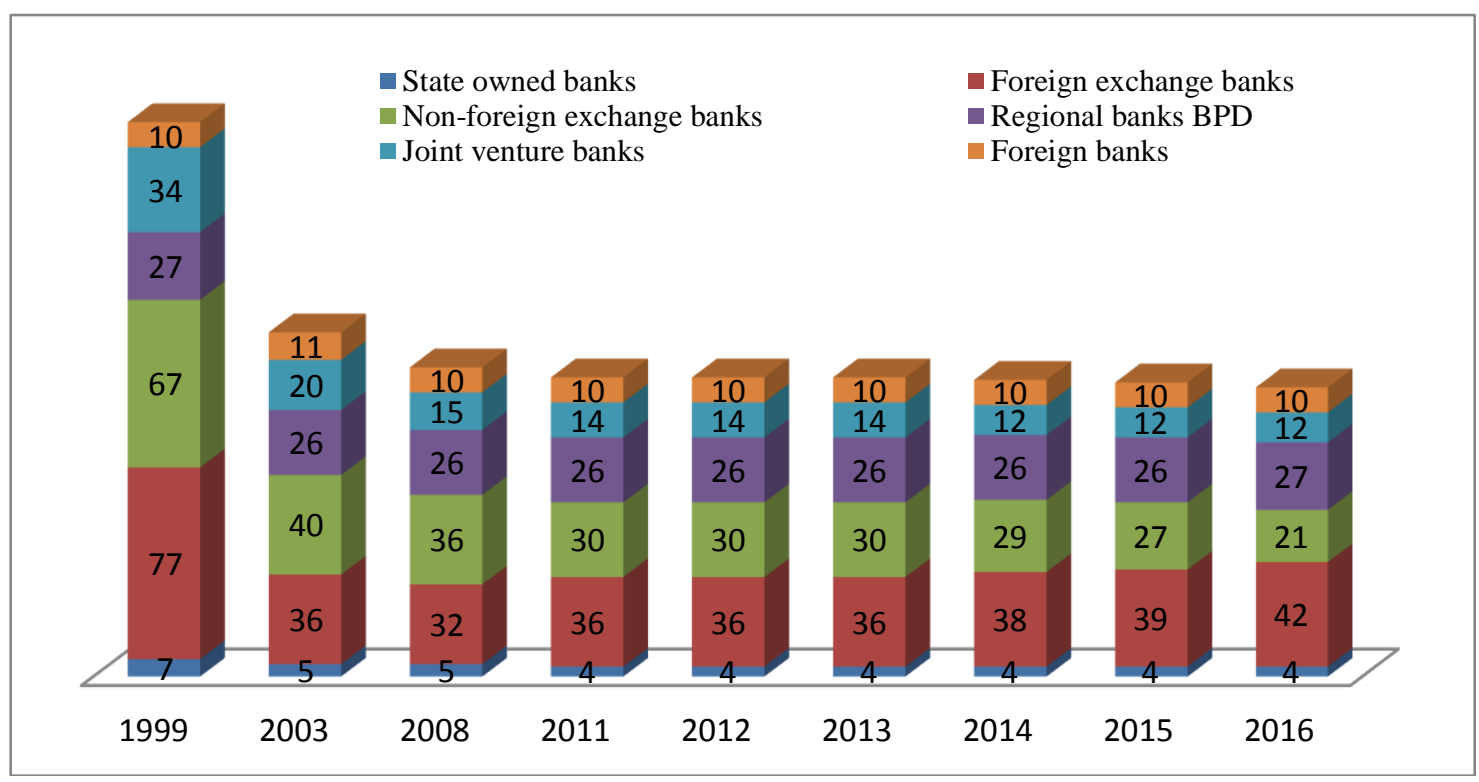

Figure 1. The number of banks according to ownership classification

Sources: Bank of Indonesia, The Financial Services Authority, 2016 (processed)

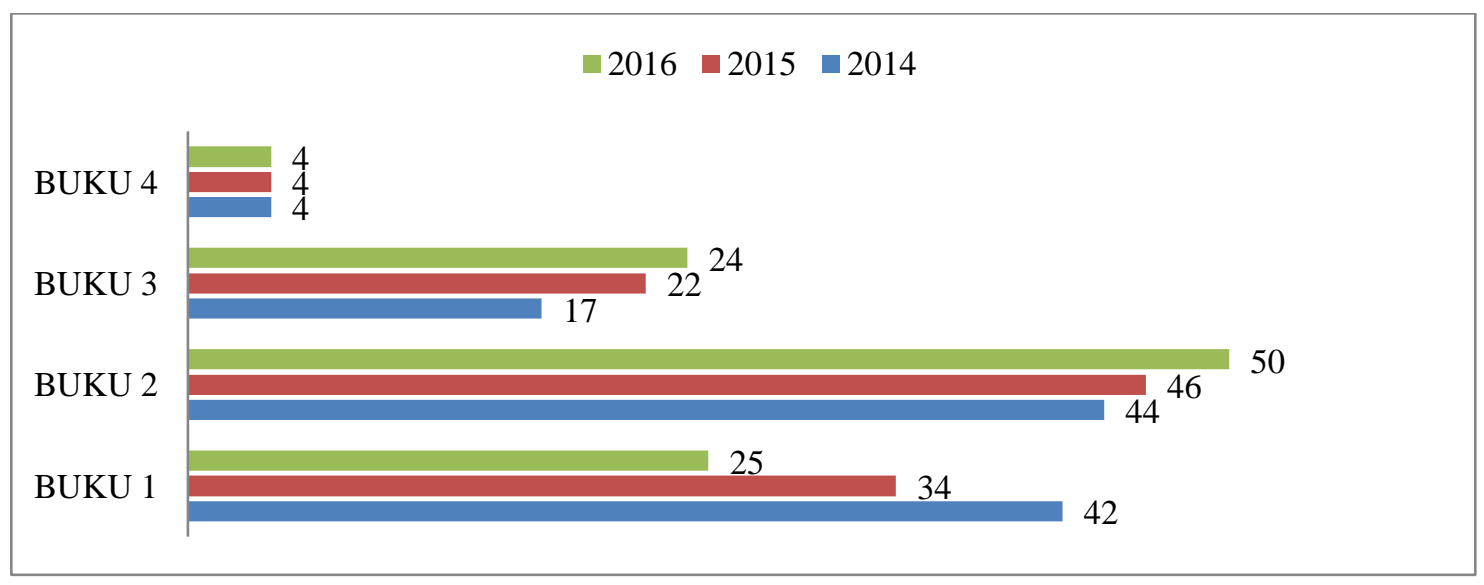

Figure 2. Number of banks based on core capital (BUKU group)

Sources: Bank of Indonesia, The Financial Services Authority, 2016 (processed)

Several previous studies conducted by Athoillah (2010), Mulyaningsih \& Daly (2011) proved that Indonesian banking industry was in a state of monopolistic. In addition, Widyastuti \& Armanto (2013) also mentioned that the Indonesian banking market was classified into a monopolistic market during the consolidation period.

There are several important grounds why this study is necessarily conducted. First, competition is an important aspect in the industry which enables the products being generated can have an impact. Second, the practice of market structures which becomes increasingly concentrated in business activities results in more intense concentration of industry which tends to reduce competition between companies. It can eventually bring about less efficient behavior. 
In order to be able to observe the extent to which the banking competitiveness exists, the method of Panzar Rosse model is proposed. Bikker \& Haaf (2002) stated that the Panzar Rosse model is able to prove that monopoly can increase input prices in order that they can increase marginal costs, while they can reduce output and income; thus, the resulting value will be zero or negative. Broadly defined, Panzar Rosse model is a nonstructural approach which assesses the level of competition based on the cost structure assuming that the bank operates in a long-term market equilibrium state. In addition, the Panzar Rosse model is also considered being capable of overview on the market structure more broadly by using simple calculations using simple regression model (Shaffer, 2004).

Panzar Rosse model employs the $\mathrm{H}$-statistical concept which will generate quantitative assessments on market competition. The $\mathrm{H}$-stat value is obtained from the sum of the elasticity of the input price by using the revenue value to determine the market structure. The basic concept of this method is that the changes in input prices can affect other changes in income. Initially, a research which employed Panzar Rosse method was first conducted by Shaffer (1982) and Molyneux, Thornton \& Lloyd-Williams (1996), both of whom showed the research results that the market indicated monopolistic competition. Furthermore, Anzoategui, Pería, \& Melecky (2012) proved that the level of competition in the banking industry is one of the most important factors in depicting how bank products can create a major impact on banking sector. In addition, the role of the government, such as their intervention in establishing other policies, also drives a major influence in the banking industry.

The novelty in this study is the Panzar Rosse test conducted on all banks in the industry, besides that it is also conducted tests on banks based on the group of each bank, this has never been done together before. The hypothesis of this study is how the competitive conditions in the Indonesian banking industry, whether in a state monopoly, monopolistic competition or perfect competition, and whether there is a difference if the Panzar Rosse test is based on a bank group.

\section{LITERATURE REVIEW}

Firstly developed by Panzar and Rose in 1987, the Panzar Rosse model is a nonstructural model which identifies the level of competition in the printing industry. In both of their researches (Panzar \& Rosse, 1987; Rosse \& Panzar, 1977) they formulated a simple model for measuring oligopoly markets, perfect competition and monopoly, and also developed a test to distinguish between these models. The method of Panzar Rosse (PR) reduces the form of equation and acceptance through utilizing company's income and price data. The evaluation is performed based on the nature of the reduction in the form of income equations in banks using the $\mathrm{H}$ statistical test as a measure of the level of competition in the banking (Vesalla, 1995). The value of $\mathrm{H}$ can empirically distinguish prices in imperfect competition, ranging from monopoly, monopolistic competition to perfect competition (Bikker \& Haaf, 2002). In addition, according to Spierdijk \& Shaffer (2015), Panzar Rosse is a measure commonly used in assessing the strength of banking market. Shaffer (2004) in his research stated that the Panzar Rosse model uses data from company-level with $\mathrm{H}$ test statistics to capture the level of competition in banking.

In the study conducted by Kashi, Beynabadi \& Mosavi. (2015), they show that level of concentration declined when structural changes occured in banking. The results of the Panzar Rosse test showed that the Wald Test rejects the hypothesis assuming that the market is monopolistic or perfect competition. Therefore, it infers that total income of bank is earned in monopolistic market state. In contrast to them, Yuan (2006) in his research claimed that banking in China is close to the market of perfect competition with a very competitive market. 
To measure the competitiveness of a market in an industry, it requires a method which was initially introduced by Panzar \& Rosse (1987) which is in a form of equality of income and prices. Vesalla (1995) provided the $\mathrm{H}$ sign for the sum of income and prices, in which, if $\mathrm{H}$-stat obtained is less or equal to zero, the market tends to be either monopoly or oligopoly. On the other hand, if the value of $\mathrm{H}$ is equal to unity, it means that the market experiences perfect competition.

Table 1. Discriminatory power of $\mathrm{H}$

\begin{tabular}{ll}
\hline $\mathrm{H}$ value & \multicolumn{1}{c}{ Competitive environment } \\
\hline $\mathrm{H} \leq 0$ & $\begin{array}{l}\text { Monopoly state: each bank operates independently, maximizes profits ( } \mathrm{H} \text { is a } \\
\text { derivative function of demand elasticity) }\end{array}$ \\
$0<\mathrm{H}<1$ & $\begin{array}{l}\text { Monopolistic competition with free entry conditions. Each of competing } \\
\text { companies has unequal market power }\end{array}$ \\
$\mathrm{H}=1$ & Perfect competition, free to enter the state with efficient capacity utilities \\
\hline
\end{tabular}
Source: Bikker \& Raaf (2002)

In a perfectly competitive market, an increase in input prices will lead to an increase in average cost, or in the long run, the price set will be equal to the average cost it incurs. In other words, it will increase the output price to maintain profitability. When companies quit from the competition, it will cause an increase in demand, which will eventually lead to increase in prices and revenues equal to the costs increment (Bikker \& Haaf, 2002). Meanwhile, in monopolistic competition or collusive oligopoly, increased marginal costs occur when input costs increase; thus resulting in decreased income.

Bikker \& Haaf (2002) in their research revealed that $H$ values can empirically provide a difference within the process of price formation in the theory of imperfect competition. Panzar Rosse's empirical model assumes that banks have income and cost functions in the form of linear log.

$$
\begin{aligned}
& L n(M C)=a 0+a 1 \ln (\text { out })+\sum_{i=1}^{m} \beta i \ln (F I P i)+\sum_{j=1}^{p} \gamma i \ln (E X \cos t, i) \\
& L n(M R)=\delta 0+\delta 1 \ln (\text { out })+\sum_{k=1}^{q} \varphi i \ln (\text { EX revenue }, i)
\end{aligned}
$$

Where OUT represents output, $n$ denotes the number of banks, FIP is the input price and

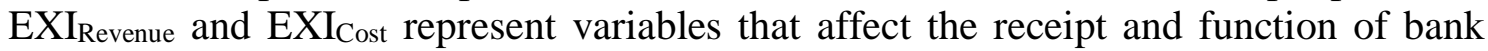
costs, respectively. The empirical application approach of Panzar and Rosse assumes the log-linear function marginal cost for banks i.

In addition, PR also models profit maximization which will be generated at a level where the marginal cost is equal to marginal revenue, resulting in equilibrium values for output:

$\operatorname{Ln}($ OUT $)=\frac{\left(a_{0}-\delta_{0}+\sum_{i=1}^{m} \beta i \ln (F I P i)+\sum_{j=1}^{p} \gamma i \ln (\text { EXi,cost })-\sum_{k=1}^{q} \varphi i \ln (\text { EXi,revenue })\right)}{\delta 1-\alpha 1}$.

The equation model of revenue earned as follows (Bikker \& Haaf, 2002):

$$
\operatorname{Ln}(\text { TIRit })=\alpha_{\mathrm{i}}+\left(\beta \operatorname{Ln}\left(A F R_{i t}\right)+\gamma \operatorname{Ln}\left(P C E_{i t}\right)\right)+\sigma \operatorname{Ln}\left(\mathrm{OI}_{\mathrm{it}}\right)+\sum_{j}\left(B S F_{j i t}\right)+\mathrm{e}_{\mathrm{it}}
$$

According to Yeyati \& Micco (2007), TIR is the ratio of interest income to the total balance sheet, while AFR is the price of funding; HALE is labor costs (wage rate); PCE is the price of capital expenditure; $\mathrm{OI}$ is the ratio of other income to the total balance sheet, and BSF is exogenous specific factors of a bank, such as the risk component, the difference in deposit mix and the size of the bank's real assets.

$\mathrm{H}$ is the value of elasticity in the equation of income which is described by price. 
$H=\sum_{j} \frac{\vartheta R i}{\vartheta F I P j, i} \frac{\vartheta F I P j, i}{\vartheta R i}$

$H=\beta+\gamma+\vartheta$

The value of $\mathrm{H}$ can be calculated using $\beta$ as the funding elasticity against the changes in funding costs, $\gamma$ as income elasticity to the changes in human resources, and $\vartheta$ is defined as income elasticity to changes in capital prices.

Bikker \& Haaf (2000) conducted a study using Panzar Rosse model carried out in 23 countries for 10 years, the results of which revealed that the banking market was characterized by monopolistic competition. Banks competition became stronger for large banks (operating in the international market) while increasingly weak for small banks which operated locally. In the researches carried out in several countries, it was obvious that the competition in the European market was more intense in comparison with other counterpart. In addition, in another study, Bikker \& Haaf (2002) stated that the Panzar Rosse model can prove that monopolies can increase input prices in order that they can increase marginal costs, while output and income are reduced to gain $\mathrm{H}$ value to be zero or negative.

There are several assumptions to be taken into account when using the Panzar Rosse method. According to Gelos \& Roldos (2002), one must regard the banks as the industries which can maximize profits with their own revenue through cost functions and that the market is in a long-run equilibrium condition. De Bandt \& Davis (2000) proposed that a bank is a company which creates a single product that acts as a financial intermediary, and that high input prices are not related to the quality of services; thus, they can generate high income.

\section{RESEARCH METHOD}

To measure the level of competition in the banking market, the study performed a test based on the form of an equation of a structural model. A form of linear log of the Panzar Rosse model of revenue and cost functions is formulated as follows (Claessens \& Laeven, 2003):

$$
\ln \left(\mathrm{P}_{i t}\right)=\alpha_{0}+\beta \ln \left(W 1_{i t}\right)+\gamma \ln \left(W 2_{i t}\right)+\delta \ln \left(W 3_{i t}\right)+\lambda_{1} \ln \left(Y 1_{i t}\right)+\lambda_{2} \ln \left(Y 2_{i t}\right)+\lambda_{3} \ln \left(Y 3_{i t}\right)+\varepsilon_{i t}
$$

Where, subscript i represents a bank, while t denotes a year, $\mathrm{P}_{\text {it }}$ is ratio of interest income/ total assets. For the proxy of prices, the following variables apply:

$\mathrm{W} 1_{\mathrm{it}}$ : Ratio of interest expense/total savings;

$\mathrm{W} 2_{\mathrm{it}}$ : Ratio of personnel expense/total assets

W3 $3_{\text {it: }}$ Ratio of operational and administrative expense/total assets.

The model (7) also includes several variables to control each bank. The controller variables are:

$\mathrm{Y} 1_{\text {it: }}$ Ratio of capital/total assets;

Y $2_{\text {it: }}$ Ratio of credit/total assets;

Y 3 it: Total asset value.

From the model (7), the H-stat value is obtained and used to determine the structure of the Indonesian banking market. One of the assumptions the Panzar Rosse method applies is that market conditions are equilibrium. In such a model, E-stat is considered equilibrium by conducting $\mathrm{F}$ test. If the $\mathrm{F}$ test is rejected, in the long term, the market will stay in a disequilibrium state. The equilibrium model is derived from the main model of PR by modification to:

$$
\ln \left(R O A_{i t}\right)=\alpha_{0}+\beta \ln \left(W 1_{i t}\right)+\gamma \ln \left(W 2_{i t}\right)+\delta \ln \left(W 3_{i t}\right)+\lambda_{1} \ln \left(Y 1_{i t}\right)+\lambda_{2} \ln \left(Y 2_{i t}\right)+\lambda_{3} \ln \left(Y 3_{i t}\right)+\varepsilon_{\mathrm{it}} \ldots . .(8)
$$


Table 2. Operational variables

\begin{tabular}{|c|c|c|}
\hline Variable & Indikator & Measurement \\
\hline \multirow{3}{*}{ Competition } & $\begin{array}{l}\text { Interest } \\
\text { Revenue }\end{array}$ & Ratio of interest income/total assets \\
\hline & $\begin{array}{l}\text { Input } \\
\text { Prices }\end{array}$ & $\begin{array}{l}\mathrm{W} 1_{\mathrm{it}} \text { : Ratio of interest expense/total savings; } \\
\mathrm{W} 2_{\mathrm{it}} \text { : Ratio of personnel expense/total assets; } \\
\mathrm{W} 3_{\mathrm{it}} \text { : Ratio of operational and administrative expense/total assets. }\end{array}$ \\
\hline & $\begin{array}{l}\text { Variabel } \\
\text { Control }\end{array}$ & $\begin{array}{l}\mathrm{Y} 1_{\text {it }}: \text { Ratio of capital/total assets; } \\
\text { Y } 2_{\text {it }}: \text { Ratio of credit/total assets; } \\
\text { Y } 3_{\text {it }}: \text { Total asset value. }\end{array}$ \\
\hline
\end{tabular}

The present research was conducted from 2006 to 2016, during which, the number of commercial banks in Indonesia up to 2016 was 116 entities. However, to set the limit of the scope of the study, the purposive sampling technique was used in order to obtain a total sample of 84 banks.

\section{RESULTS AND DISCUSSION}

In conducting the test of Panzar Rosse model, an equilibrium test is firstly performed by replacing the dependent variable with the ROA one using the F test. Based on the equilibrium test results on the E-stat model, it revealed that the hypothesis $\mathrm{E}=0$ is accepted, or in other words it can be concluded that in the long-term conditions, the market of banking industry is in equilibrium state.

The $H$-stat value is obtained by combining the $\beta+\gamma+\vartheta$ coefficient based on the input variables of funds, labor and capital which will be used to generate income, while the others are controlling variables. Based on results of data processing, the value of $\mathrm{H}$ stat is presented in Table 3 and 4.

Table 3. Panel data regression analysis of model PR (Dependent variable: $\mathrm{LN}(\mathrm{P})$ )

\begin{tabular}{crrrrrrr}
\hline $\begin{array}{c}\text { Independent } \\
\text { variable }\end{array}$ & All banks & $\begin{array}{c}\text { State owned } \\
\text { banks }\end{array}$ & $\begin{array}{c}\text { Foreign } \\
\text { exchange } \\
\text { banks }\end{array}$ & $\begin{array}{c}\text { Non-foreign } \\
\text { exchange } \\
\text { banks }\end{array}$ & $\begin{array}{c}\text { Regional } \\
\text { banks BPD }\end{array}$ & $\begin{array}{c}\text { Joint venture } \\
\text { banks }\end{array}$ & $\begin{array}{c}\text { Foreign } \\
\text { banks }\end{array}$ \\
\hline C & 0.4544 & -3.5255 & 0.8835 & -1.1440 & 0.7944 & 3.2943 & -10.9941 \\
LN(W1) & $(0.0309)$ & $(0.0720)$ & $(0.0336)$ & $(0.0124)$ & $(0.0460)$ & $(0.0016)$ & $(0.0000)$ \\
& 0.2090 & 0.4912 & 0.2943 & 0.1730 & 0.0846 & 0.2702 & -0.1229 \\
LN(W2) & $(0.0000)$ & $(0.0000)$ & $(0.0000)$ & $(0.0000)$ & $(0.0000)$ & $(0.0001)$ & $(0.0391)$ \\
& 0.2334 & 0.3619 & 0.0086 & 0.1311 & 0.1241 & 0.2206 & 1.0108 \\
LN(W3) & $(0.0000)$ & $(0.0000)$ & $(0.8748)$ & $(0.0043)$ & $(0.0001)$ & $(0.0041)$ & $(0.0000)$ \\
& 0.1445 & -0.1122 & 0.1871 & 0.0603 & 0.0649 & 0.3417 & -0.2716 \\
LN(Y1) & $(0.0000)$ & $(0.2524)$ & $(0.0002)$ & $(0.1700)$ & $(0.0173)$ & $(0.0000)$ & $(0.0024)$ \\
& 0.0394 & -0.2724 & -0.0307 & -0.1402 & 0.1335 & -0.4033 & -0.0407 \\
LN(Y2) & $(0.0006)$ & $(0.0095)$ & $(0.3559)$ & $(0.0000)$ & $(0.0001)$ & $(0.0000)$ & $(0.1272)$ \\
& 0.3143 & 0.3865 & 0.2257 & 0.2364 & 0.3551 & 0.2541 & -0.1754 \\
LN(Y3) & $(0.0000)$ & $(0.0001)$ & $(0.0000)$ & $(0.0000)$ & $(0.0000)$ & $(0.0013)$ & $(0.0374)$ \\
& -0.1969 & 0.9522 & -0.6052 & -0.0217 & -0.5651 & -1.1890 & 3.8399 \\
& $(0.0150)$ & $(0.1236)$ & $(0.0000)$ & $(0.9099)$ & $(0.0010)$ & $(0.0031)$ & $(0.0000)$ \\
\hline R-squared & 0.6122 & 0.8295 & 0.5071 & 0.434 & 0.7366 & 0.7108 & 0.7041 \\
Adj R-squared & 0.6099 & 0.8039 & 0.4853 & 0.4185 & 0.7312 & 0.6913 & 0.673 \\
F-statistic & 259.4561 & 32.424 & 23.3185 & 28.1097 & 134.7239 & 36.4624 & 22.6062 \\
Prob(F-statistic) & 0.0000 & 0.0000 & 0.0000 & 0.0000 & 0.0000 & 0.0000 & 0.0000 \\
H-stat & 0.5869 & 0.7408 & 0.49 & 0.3644 & 0.2735 & 0.8325 & 0.6163 \\
Market structure & Monopolistic & Monopolistic & Monopolistic & Monopolistic & Monopolistic & Monopolistic & Monopolistic \\
\hline Notes: Probability in parentheses & & & & & & &
\end{tabular}


Table 4. Panel data regression analysis of model PR (by group of BUKU, Dependent Variable: $\mathrm{LN}(\mathrm{P}))$

\begin{tabular}{crrrr}
\hline \multicolumn{1}{c}{ Independent variable } & BUKU 1 & BUKU 2 & BUKU 3 & BUKU 4 \\
\hline C & $-2,8297$ & $-2,5678$ & $-4,2223$ & $-12,9935$ \\
LN(W1) & $(0,0000)$ & $(0,0455)$ & $(0,0083)$ & $(0,0037)$ \\
& 0,1582 & 0,2487 & 0,2631 & 0,1446 \\
LN(W2) & $(0,0000)$ & $(0,0000)$ & $(0,0000)$ & $(0,3110)$ \\
& 0,1630 & 0,2485 & 0,2086 & 0,6094 \\
LN(W3) & $(0,0000)$ & $(0,0000)$ & $(0,0000)$ & $(0,0000)$ \\
& 0,0917 & 0,1922 & 0,1985 & $-0,0091$ \\
LN(Y1) & $(0,0030)$ & $(0,0000)$ & $(0,0000)$ & $(0,9506)$ \\
& 0,0743 & 0,0653 & 0,1181 & $-0,2580$ \\
LN(Y2) & $(0,0000)$ & $(0,0016)$ & $(0,0054)$ & $(0,1375)$ \\
LN(Y3) & 0,3803 & 0,3529 & 0,3468 & 0,2906 \\
& $(0,0000)$ & $(0,0000)$ & $(0,0008)$ & $(0,3327)$ \\
& 0,8543 & 1,0261 & 1,5504 & 4,3166 \\
Adj R-squared & $(0,0000)$ & $(0,0216)$ & $(0,0041)$ & $(0,0018)$ \\
F-statistic & 0,6095 & 0,6075 & 0,7244 & 0,8296 \\
Prob(F-statistic) & 0,6045 & 0,5990 & 0,7120 & 0,7695 \\
H-stat & 120,4595 & 71,4578 & 58,2598 & 13,7951 \\
Market structure & 0,0000 & 0,0000 & 0,0000 & 0,0000 \\
\hline Ros & 0,4128 & 0,6894 & 0,6701 & 0,7449 \\
& Monopolistic & Monopolistic & Monopolistic & Monopolistic \\
\hline
\end{tabular}

Notes: Probability in parentheses

The results of measurement indicate the effect of each independent variable on the dependent variable (Tables 3 and 4). Each variable shows a significant effect with a probability less than $0.05(5 \%)$. Based on the probability test on the overall bank, it shows that all significant variables affect income, while for the state-owned banks and nonforeign exchange banks; there are 2 variables which has a value of probability more than $10 \%$. It can be seen in the variables $\ln (\mathrm{w} 3)$ and $\ln (\mathrm{y} 3)$, which are the ratio of operating expenses to total assets and total asset ratio. In foreign exchange banks, there are 2 insignificant variables as seen in the variables $\ln (\mathrm{w} 2)$ and $\ln (\mathrm{y} 1)$, namely the personnel expense variable on total assets and the credit expense on total assets. At last, for foreign banks, there is an insignificant variable $\ln (\mathrm{y} 1)$.

Meanwhile, when viewed based on the BUKU of banks classification, there are only 2 significant variables for their dependent variables $\ln (\mathrm{w} 2)$ and $\ln (\mathrm{y} 3)$. Based on the Table 4, it shows that although there are insignificant variables, if tested simultaneously, the research variables still have a significant influence. It can be seen based on the R-squared and Adj R-square values which are more than 50\% except for non-foreign exchange banks, which is slightly below 0.5 . In addition, based on banks classification by core capital, the banks of BUKU 4 group are more likely to be more competitive given that they are only dominated by the 4 largest banks in Indonesia. As such, the competition will be increasingly intense among these banks. However, the results of the research is not in line with those conducted by Yeyati \& Micco (2007) in 
which they found that the banking market of large group is in the form of a monopoly yet it is the least competitive.

In addition, Figure 3 shows the $\mathrm{H}$-stat results for all banking sectors and all BUKU categories in a state of monopolistic competition market. For BPD (regional banks) banks, the $\mathrm{H}$-stat value tends to approach $\mathrm{H}=0(0.2735)$ which indicates that the market tends to be monopoly (short oligopoly). Meanwhile, the H-stat values of joint venture banks category tends to approach $\mathrm{H}=1(0.8325)$ which means that the banks classified into the group nearly approach the perfect competition market.

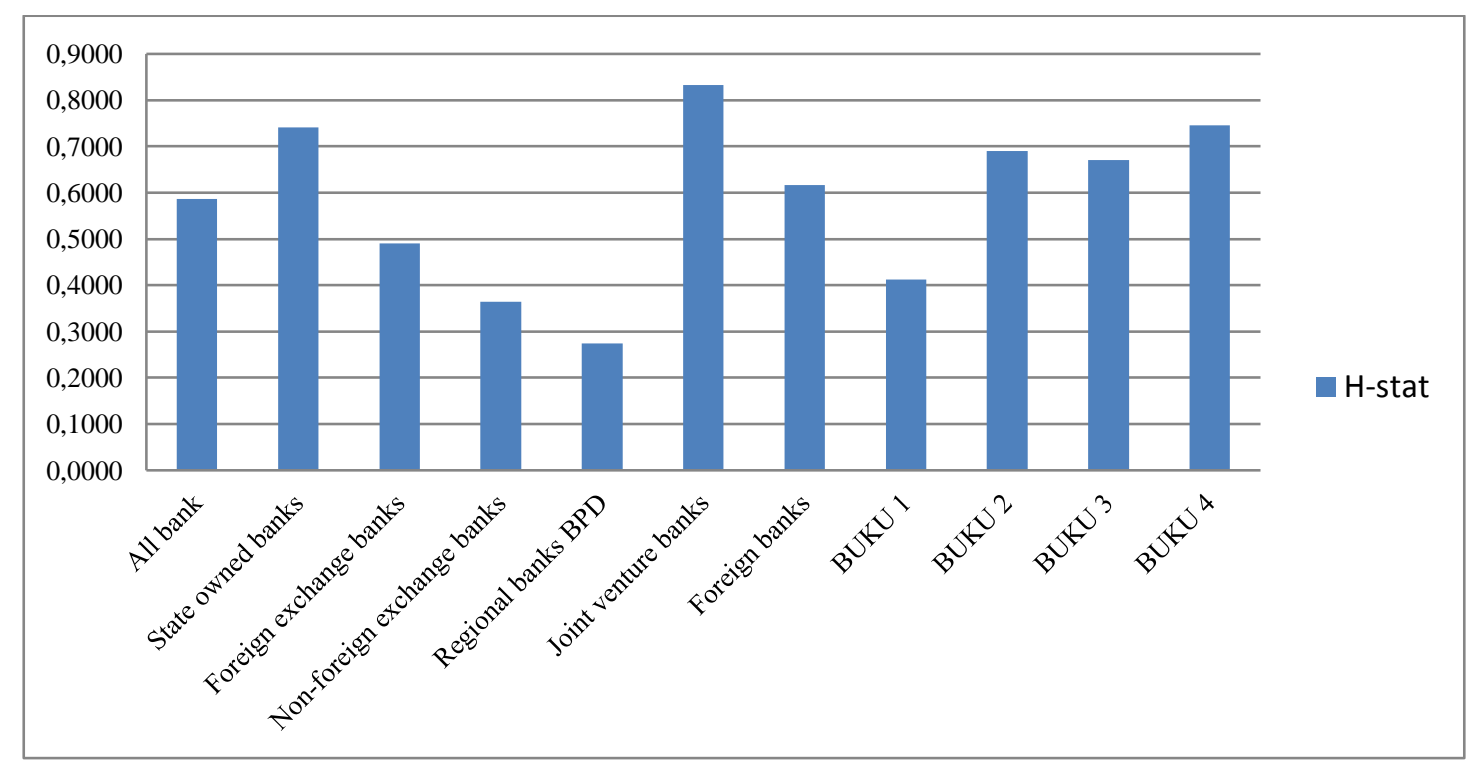

Figure 3. Analysis results of Panzar Rosse H-stat by banks classification Sources: Regression analysis, 2018 (processed)

The results of $\mathrm{H}$-stat are an assumption that an increase in costs of inputs may occur as a result of increased banking output, which indicates that there is a linear correlation between input and banking income. When prices of input increase, banking revenues will increase.

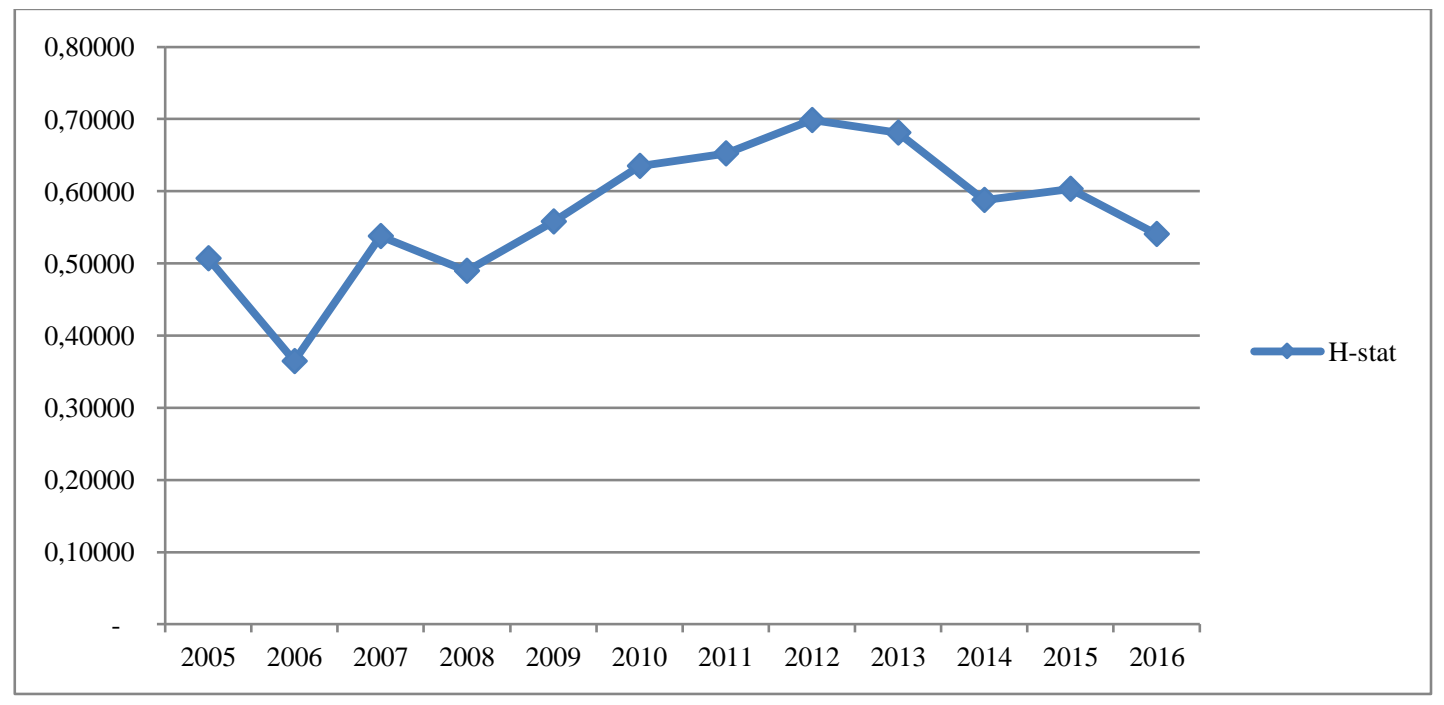

Figure 4. H-stat of Panzar Rosse test results Sources: Regression analysis, 2018 (processed) 
The results in Figure 4 show that during the research period, the bank was in monopolistic competition with $\mathrm{H}$-stat values ranged from 0 to 1 . Referring to Table 3 , it can be seen that the H-stat value of the whole banks in the sample of study was 0.58694 , which indicated that the market was monopolistic competition $(0<\mathrm{H}$-stat $<1)$ with free entry conditions where each of competing companies has unequal market power (Bikker \& Raaf, 2002). Thus, this study finding is consistent with the results of previous studies conducted by Shaffer (1985, 1993), Casu \& Girardone (2006), Claessens \& Leaven (2004), Majid \& Sufian (2007), Aysan \& Abbasoglu (2007), Athoillah (2010), Widyastuti $\&$ Armanto (2013) during the consolidation period.

\section{CONCLUSIONS AND RECOMMENDATIONS}

\section{Conclusion}

The model of Panzar Rosse employed to model banking competition in Indonesia during the research period shows that the market is in an equilibrium state for the long term. Based on the results of the study, on average Indonesian banking industry is in monopolistic market state given the value of $\mathrm{H}$-stat is 0.58694 . It indicates that any increase in input prices will have an impact on bank income.

Meanwhile, the competitiveness of banking industry based on bank size categorized by its core capital, is more intense among large and medium banks (banks of BUKU 4, 2 , and 1), whereas it is lesser in small-scale banks (banks of BUKU 4).

\section{Recommendations}

The limitation of this study is that this study only looks at the competition variable, and has not seen its relationship with other variables. In subsequent studies, it is expected to conduct research related to competition and relate it to other variables, such as market share or level of market concentration. In addition, it can conduct research related to how competition can affect the level of banking efficiency in Indonesia.

\section{REFERENCES}

Anzoategui, D., Pería, M.S.M \& Melecky, M. (2012). Bank Competition in Russia: An Examination at Different Levels of Aggregation. Emerging Markets Review, 13 (1), 42-57.

Athoillah, M. (2010). Struktur Pasar Industri Perbankan Indonesia: Rosse-Panzar Test. Journal of Indonesian Applied Economics, 4 (1), 1-10.

Aysan, A., Gunes, A., \& Abbasoglu, O. (2007). Concentration, Competition, Efficiency and Profitabliti of the Turkish Banking sector in the Post-Crises Period. Working Papers, Bogazici University, Department of Economics.

Bikker, J.A. \& Haaf, K. (2002). Competition, Concentration and their Relationship: an Empirical Analysis of the Banking Industry. Journal of Banking \& Finance, 26 (1), 2191-2214.

Bikker, J.A. \& Groeneveld, J.M. (2000). Competition and Concentration in the EU Banking Industry, Kredit und Kapital, 33, 62-98.

Casu, B., \& Girardone, C. (2006). Bank Competition, Concentration and Efficiency in the Single European Market. The Manchester School, 74 (4), 441- 468.

Claessens, S. \& Laeven, L. (2003). What Drives Bank Competition? Some International Evidence. Journal of Money, Credit, and Banking, 36 (3), 563-584.

De Bandt, O. \& Davis, E.P., (2000). Competition, contestability and market structure in European banking sectors on the eve of EMU. Journal of Banking \& Finance, 24(6), 1045-1066. 
Gelos, G. \& Roldos, J. (2002). Consolidation and Market Structure in Emerging Market Banking Systems. Working Paper, International Monetary Fund.

Kashi, F.K, Beynabadi, J.Z. \& Mosavi, Y., (2015). Competition In Iran's Banking Sector: Panzar-Rosse Approach. Iran. Econ. Rev. 19(1), 29-39.

Majid,A.M.Z. \& Sufian, F. (2006). Consolidation and Competition in Emerging Market: an Empirical Test for Malaysian Banking Industry. Economic Change and Restructuring, 39(1-2), 105-124.

Molyneux, P., Thornton, J. \& Lloyd-Williams,D.M. (1996). Competition and Market Contestability in Japanese Commercial Banking. Journal of Economics and Business, 48(1), 33-45.

Mulyaningsih, T. \& Daly, A. (2011). Competitive Conditions in Banking Industry: An Empirical Analysis of The Consolidation, Competition And Concentration In The Indonesia Banking Industry Between 2001 and 2009. Buletin Ekonomi, Moneter dan Perbankan, 14(2), 151-186.

Panzar, J. \& Rosse, J. (1987). Testing for ‘monopoly' Equilibrium. Journal of Industrial Economics, 35(4), 443-456.

Rosse, J. \& Panzar, J. (1977). Chamberlin vs Robinson: an Empirical Study for Monopoly Rents, Bell Laboratories Economic Discussion Paper.

Shaffer, S. (1982). A non-structural tests for competition in financial markets, Bank Structure and Competition, Conference Proceedings, Federal Reserve Bank of Chicago, Chicago, 225-243.

Shaffer, S. (2004). Patterns of competition in banking, Journal of Economics and Business, 56 (4), 287-313.

Spierdijk, L. \& Shaffer, S. 2015. The Panzar-Rosse Revenue Test and Market Power in Banking. Journal of Banking Finance, 61, 340-347

Vesala, J. (1995). Testing for Competition in Banking: Behavioral Evidence from Finland. Finland: Suomen Pankki.

Widyastuti, R.S. \& Armanto, B. (2013). Kompetisi Industri Perbankan Indonesia. Buletin Ekonomi Moneter dan Perbankan, 12(1), 129-142.

Yeyati, E.L. \& Micco, A. (2007). Concentration and Foreign Penetration in Latin American Banking Sectors: Impact on Competition and Risk. Journal of Banking and Finance, 31 (6), 1633-1647.

Yuan, Y. (2006). The state of competition of the Chinese banking industry. Journal of Asian Economics, 17 (3), 519-534. 
APPENDIX: List of banks

\begin{tabular}{|c|c|c|c|c|}
\hline No & Bank & ID_Bank & Bank Type & BUKU \\
\hline 1 & PT Bank Negara Indonesia (Persero) Tbk & 009 & State owned banks & BUKU 4 \\
\hline 2 & PT Bank Rakyat Indonesia (Persero). Tbk. & 002 & State owned banks & BUKU 4 \\
\hline 3 & PT Bank Tabungan Negara (Persero) & 200 & State owned banks & BUKU 3 \\
\hline 4 & PT. Bank Mandiri (Persero). Tbk. & 008 & State owned banks & BUKU 4 \\
\hline 5 & PT Bank Bukopin. Tbk & 441 & Foreign exchange banks & BUKU 3 \\
\hline 6 & PT Bank Bumi Arta. Tbk & 076 & Foreign exchange banks & BUKU 2 \\
\hline 7 & PT Bank Central Asia Tbk. & 014 & Foreign exchange banks & BUKU 4 \\
\hline 8 & PT Bank Danamon Indonesia Tbk & 011 & Foreign exchange banks & BUKU 3 \\
\hline 9 & PT Bank Ganesha & 161 & Foreign exchange banks & BUKU 2 \\
\hline 10 & PT Bank ICBC Indonesia & 164 & Foreign exchange banks & BUKU 2 \\
\hline 11 & PT Bank Maspion Indonesia & 157 & Foreign exchange banks & BUKU 2 \\
\hline 12 & PT Bank Mayapada International Tbk & 097 & Foreign exchange banks & BUKU 3 \\
\hline 13 & PT Bank Mega. Tbk & 426 & Foreign exchange banks & BUKU 3 \\
\hline 14 & PT Bank Mestika Dharma & 151 & Foreign exchange banks & BUKU 2 \\
\hline 15 & PT Bank Jtrust Indonesia & 095 & Foreign exchange banks & BUKU 2 \\
\hline 16 & PT Bank Nusantara Parahyangan.Tbk & 145 & Foreign exchange banks & BUKU 2 \\
\hline 17 & PT Bank Of India Indonesia. Tbk & 146 & Foreign exchange banks & BUKU 2 \\
\hline 18 & PT Bank Permata Tbk & 013 & Foreign exchange banks & BUKU 3 \\
\hline 19 & PT Bank Rakyat Indonesia Agroniaga. Tbk. & 494 & Foreign exchange banks & BUKU 2 \\
\hline 20 & PT Bank SBI Indonesia & 498 & Foreign exchange banks & BUKU 2 \\
\hline 21 & PT Bank Sinarmas. Tbk & 153 & Foreign exchange banks & BUKU 2 \\
\hline 22 & PT Pan Indonesia Bank. Tbk & 019 & Foreign exchange banks & BUKU 3 \\
\hline 23 & PT Bank QNB Indonesia Tbk & 167 & Non-foreign exchange banks & BUKU 2 \\
\hline 24 & PT Bank Amar Indonesia & 531 & Non-foreign exchange banks & BUKU 1 \\
\hline 25 & PT Bank Oke & 466 & Non-foreign exchange banks & BUKU 1 \\
\hline 26 & PT Bank Artos Indonesia & 542 & Non-foreign exchange banks & BUKU 1 \\
\hline 27 & PT Bank Bisnis Internasional & 459 & Non-foreign exchange banks & BUKU 1 \\
\hline 28 & PT Bank Dinar Indonesia & 526 & Non-foreign exchange banks & BUKU 1 \\
\hline 29 & PT Bank Fama Internasional & 562 & Non-foreign exchange banks & BUKU 1 \\
\hline 30 & PT Bank Harda Internasional & 567 & Non-foreign exchange banks & BUKU 1 \\
\hline 31 & PT Bank Ina Perdana & 513 & Non-foreign exchange banks & BUKU 1 \\
\hline 32 & PT Bank Jasa Jakarta & 472 & Non-foreign exchange banks & BUKU 2 \\
\hline 33 & PT Bank Kesejahteraan Ekonomi & 535 & Non-foreign exchange banks & BUKU 1 \\
\hline 34 & PT Bank Mayora & 553 & Non-foreign exchange banks & BUKU 2 \\
\hline 35 & PT Bank Mitraniaga & 491 & Non-foreign exchange banks & BUKU 1 \\
\hline 36 & PT Bank Multiarta Sentosa & 548 & Non-foreign exchange banks & BUKU 2 \\
\hline 37 & PT Bank Nationalnobu & 503 & Non-foreign exchange banks & BUKU 2 \\
\hline 38 & PT Bank Royal Indonesia & 501 & Non-foreign exchange banks & BUKU 1 \\
\hline 39 & PT Bank Sahabat Sampoerna & 523 & Non-foreign exchange banks & BUKU 2 \\
\hline 40 & PT Bank Tabungan Pensiunan Nasional. Tbk & 213 & Non-foreign exchange banks & BUKU 3 \\
\hline 41 & PT Bank Victoria International. Tbk & 566 & Non-foreign exchange banks & BUKU 2 \\
\hline 42 & PT Bank Yudha Bhakti & 490 & Non-foreign exchange banks & BUKU 1 \\
\hline 43 & BPD Sulawesi Tenggara & 135 & Regional banks BPD & BUKU 1 \\
\hline 44 & BPD Yogyakarta & 112 & Regional banks BPD & BUKU 2 \\
\hline 45 & BPD Kalimantan Timur & 124 & Regional banks BPD & BUKU 2 \\
\hline 46 & PT Bank Dki & 111 & Regional banks BPD & BUKU 3 \\
\hline 47 & PT Bank Kalimantan Tengah & 125 & Regional banks BPD & BUKU 1 \\
\hline 48 & PT BPD Jambi & 115 & Regional banks BPD & BUKU 1 \\
\hline 49 & PT BPD Sulawesi Selatan \& Sulawesi Barat & 126 & Regional banks BPD & BUKU 2 \\
\hline 50 & PT BPD Lampung & 121 & Regional banks BPD & BUKU 1 \\
\hline 51 & PT BPD Riau Kepri & 119 & Regional banks BPD & BUKU 2 \\
\hline 52 & PT BPD Sumatera Barat & 118 & Regional banks BPD & BUKU 2 \\
\hline 53 & PT BPD Jawa Barat Dan Banten. Tbk & 110 & Regional banks BPD & BUKU 3 \\
\hline 54 & PT BPD Maluku & 131 & Regional banks BPD & BUKU 1 \\
\hline 55 & PT BPD Bengkulu & 133 & Regional banks BPD & BUKU 1 \\
\hline 56 & PT BPD Jawa Tengah & 113 & Regional banks BPD & BUKU 2 \\
\hline
\end{tabular}




\begin{tabular}{llccc}
\hline No & \multicolumn{1}{c}{ Bank } & ID_Bank & Bank Type & BUKU \\
\hline 57 & PT BPD Jawa Timur & 114 & Regional banks BPD & BUKU 3 \\
58 & PT BPD Kalimantan Barat & 123 & Regional banks BPD & BUKU 2 \\
59 & PT BPD Nusa Tenggara Barat & 128 & Regional banks BPD & BUKU 2 \\
60 & PT BPD Nusa Tenggara Timur & 130 & Regional banks BPD & BUKU 2 \\
61 & PT BPD Sulawesi Tengah & 134 & Regional banks BPD & BUKU 1 \\
62 & PT BPD Sulawesi Utara & 127 & Regional banks BPD & BUKU 2 \\
63 & PT BPD Bali & 129 & Regional banks BPD & BUKU 2 \\
64 & PT BPD Kalimantan Selatan & 122 & Regional banks BPD & BUKU 2 \\
65 & PT BPD Papua & 132 & Regional banks BPD & BUKU 2 \\
66 & PT BPD Sumatera Selatan \& Bangka Belitung & 120 & Regional banks BPD & BUKU 2 \\
67 & PT BPD Sumatera Utara & 117 & Regional banks BPD & BUKU 2 \\
68 & PT Bank Agris & 945 & Joint venture banks & BUKU 1 \\
69 & PT Bank Anz Indonesia & 061 & Joint venture banks & BUKU 3 \\
70 & PT Bank Bnp Paribas Indonesia & 057 & Joint venture banks & BUKU 2 \\
71 & PT Bank Capital Indonesia. Tbk & 054 & Joint venture banks & BUKU 2 \\
72 & PT Bank Dbs Indonesia & 046 & Joint venture banks & BUKU 3 \\
73 & PT Bank Mizuho Indonesia & 048 & Joint venture banks & BUKU 3 \\
74 & Bank CTBC Indonesia & 949 & Joint venture banks & BUKU 2 \\
75 & PT. Bank Sumitomo Mitsui Indonesia & 045 & Joint venture banks & BUKU 3 \\
76 & Bank Of America. N.A & 033 & Foreign banks & BUKU 2 \\
77 & Bank Of China Limited & 069 & Foreign banks & BUKU 2 \\
78 & Citibank N.A. & 031 & Foreign banks & BUKU 3 \\
79 & Deutsche Bank Ag. & 067 & Foreign banks & BUKU 3 \\
80 & Jp. Morgan Chase Bank. N.A. & 032 & Foreign banks & BUKU 2 \\
81 & Standard Chartered Bank & 050 & Foreign banks & BUKU 3 \\
82 & The Bangkok Bank Comp. Ltd & 040 & Foreign banks & BUKU 3 \\
83 & Bank MUFG & 042 & Foreign banks & BUKU 3 \\
84 & The Hongkong \& Shanghai Banking Corp & 041 & Foreign banks & BUKU 3 \\
\hline
\end{tabular}

Sources: Bank of Indonesia, The Financial Services Authority, 2016 (processed) 